\begin{tabular}{lr}
\hline \multicolumn{1}{c}{ D Y N A M I C E C O N O M E T R I C } & M O D E L S \\
DOI: http://dx.doi.org/10.12775/DEM.2018.006 & Vol. 18 (2018) 99-114 \\
\hline $\begin{array}{l}\text { Submitted November 25, 2018 } \\
\text { Accepted December 27, 2018 }\end{array}$ & ISSN (online) 2450-7067 \\
ISSN (print) 1234-3862
\end{tabular}

\title{
Rumiana Górska*
}

\section{Decomposition of Sovereign CDS Spread using the Concept of Factorization}

\begin{abstract}
A b s t r a c t. Sovereign CDS (Credit Default Swap) is a derivative that provides insurance of repayment of the government's loans and may be considered as a market indicator of the insolvency risk of a country. The aim of the study is to identify factors affecting the sovereign CDS spreads of selected European countries for the period from 2008 to 2016. Factor analysis shows that there are two common factors that have explained about $92 \%$ of the variation of the CDS spreads. Next, the decomposition of the spreads presents the influence of these factors on CDS spreads of surveyed countries.
\end{abstract}

K e y w o r d s: CDS spread; factor analysis; global risk; insolvency risk.

J E L Classification: G14; G15.

\section{Introduction}

CDS (Credit Default Swap) is a derivative that provides insurance of repayment of the loan. One of the parties of the transaction receives a specified remuneration and agrees to pay the debt to the other side of the transaction, if the debtor is unable to pay it back. Sovereign CDS is a derivative that provides insurance of repayment of the government's loans. It is often considered as a market indicator of the insolvency risk of a country. The CDS contract price (or CDS spread) is calculated as a percentage of the debt, payable annually. The higher the risk of repayment of debt, the higher the insurance premium (risk premium) required by the issuer of the CDS contracts and the higher the

* Correspondence to: Rumiana Górska, Warsaw School of Economics, Collegium of Economic Analysis, Institute of Econometrics, 6/8 Madalinskiego Street, 02-513 Warsaw, Poland, e-mail:rgorska@sgh.waw.pl.

(C) 2018 Nicolaus Copernicus University. All rights reserved. http://www.dem.umk.pl/dem 
CDS spread. CDS spreads for each country therefore reflect the confidence in the issuer of the sovereign bonds. Variation in the levels of CDS quotes for each country shows the differences in the market assessment of the risk of investments in Treasury securities of this country. For example, on 29.11.2013 sovereign CDS spreads for five-year bonds in basis points was: for Poland 82.48; Germany 23.56; Spain 153.5; Portugal 341.4. Investors holding bonds of these countries can insure themselves against the insolvency of the given country, paying annually a percentage of the value of the bond (for Poland $0.8248 \%$, Germany $0.2356 \%$, Spain $1.535 \%$, Portugal $3.414 \%$ ). CDS quotes for Greece in March 2012 (during the Greek debt crisis) reached 25422.80 basis points.

Sovereign CDS spread depends both on the so-called economic fundamentals (i.e. macroeconomic variables such as level of indebtedness, debt structure, the cost of servicing the debt, debt to GDP relation, the rate of GDP growth etc.), as well as global factors (global financial market conditions, market liquidity, investor expectations etc.).

The aim of this study is to identify factors affecting the sovereign CDS spreads of selected European countries: Germany, France, Great Britain, Italy, Spain, Portugal, Czech Republic, Hungary and Poland for the period from 2008 to 2016.

\section{Literature Review}

Publications on the issues related to the information capacity of CDS spreads securing repayment of government debt focus on different aspects of the problem. Some authors (Varga, 2008; Komarek et al., 2013; Arce et al., 2013; Coudert and Gex, 2013) examined the relationship between the CDS market and the government bonds market and came to the conclusion that prices in the market CDS and yields in the Treasury bond market reflect the same information about the credit risk of that country. Differences in the levels of spreads in the pricing of risk in both markets were associated with the following factors: counterparty risk, the lack of liquidity or liquidity problems, transaction costs, flight-to-quality and the debt repurchase decisions by the European Central Bank. Moreover, the CDS market preceded the bond market in the pricing of risk. In addition, during periods of turbulence in the financial markets, the role of the CDS markets increases.

Another group of publications includes studies of the relationship between the CDS spread and selected macroeconomic variables, market indicators or information about political events. Coronado et al. (2012) examined the relationship between the CDS market and the stock market in eight European countries for the period 2007-2010. The first of these markets represented the credit risk of the country and the second, the market risk. The authors came to 
the conclusion that the stock market leads the CDS market until 2010, the time of the first appearance of the debt crisis. Following that period, the reaction of the CDS market quickened and new information was included in the quotations of CDS for the first time. Aizenman et al. (2013) examined the pricing of risk for selected European countries based on their fiscal situation (debt, deficit, taxes) for the years 2005-2010. They considered two groups of countries: the central EU countries (Germany, France, Great Britain) and the peripheral EU (Greece, Ireland, Italy, Portugal, and Spain). In 2010 (a period of increased risk) the risk of peripheral countries was valued at a higher level than was consistent with their fiscal situation. The authors explained this effect through the mechanism of the pessimistic self-fulfilling forecasts - the expectations being that the adaptation of the peripheral countries to the new situation will be more difficult. A panel study showed that the situation of public finances and other economic variables are important determinants of a country's risk. Büchel (2013) examined the effect of public information and announcements made by the European Central Bank Governing Council members, European Union officials and National Representatives in the period 2009-2011 to the CDS and bond markets. Information from the representatives of Germany, France and the European Union authorities had an immediate effect on both markets, while the expression of representatives of smaller countries had no influence.

The third group of publications relates to the contagion effect (risk transfer) between countries. Kalbaska and Gątkowski (2012) identified the increased risk of contagion between European countries after 2007 on the basis of studying the dynamics of the CDS market in the period 2005-2010. Spain, Ireland, and Greece had the biggest impact on the destabilization of the CDS markets. The most resilient country to contagion was the United Kingdom, and the least resistant, Portugal. The aforementioned studies were conducted using econometric methods, such as the analysis of stationarity and cointegration, VECM, VAR and GARCH models, IRF analysis, and Granger causality tests.

The studies, closest in terms of the methodology of the presented here study was made by Badaou et al. (2013) and Fabozzi et al. (2016). These authors used a factor analysis framework to decompose CDS spreads. Badaou et al. (2013) identified the following components: the insolvency of the country (55.6\% of the variation) and the liquidity of the market (44.32\% of the variation). The authors concluded that increases in CDS spreads observed in times of crisis are mainly caused by the surge of liquidity, and not by an increase in the intensity of the risk of insolvency. Fabozzi et al. (2016) decompose CDS spreads using independent component analysis (a technique similar to principal component analysis) of so-called "old" EU members. 
In Poland, the issues of sovereign CDS was discussed by Kliber (2011), (2016) and Bieńkowski et al. (2011). Kliber (2011) explored the relationship between CDS spreads for three countries - Poland, Czech Republic, and Hungary. The study showed that there is a variable relationship between these instruments. During the Hungarian crisis, the relationship between prices of Polish and Hungarian CDS and that of the Czech and Hungarian CDS weakened, and during the Greek crisis, they rapidly increased. This means that global phenomena play a greater role than regional ones. Kliber (2016) also verified the impact of the ban on uncovered sovereign CDS trade in Europe on the interdependencies between the sovereign CDS market and other sectors of financial markets. The analysis of two European markets: Swedish and Hungarian shows that relationships of financial markets with the sovereign CDS was much weaker in the case of safe and developed Swedish market, so it is less prone to crisis transmission than Hungarian market. Tests made by Bieńkowski et al. (2011) on the susceptibility of the Polish currency market to internal and external instability showed, that the CDS spread belongs to the factors that cause the greatest disruption in the Polish currency market (the other factors are variables associated with the trade balance and the presence of a crisis in the peripheral European countries).

This paper extends the literature by presenting the decomposition of the CDS spread of different European countries, representing both "old" and "new" EU members, as well as the "peripheral" and the "central" countries using factor analysis and the factorization framework.

\section{Methodology}

In general, the factor analysis idea is based on the presentation of a large number of observable, correlated variables in terms of a potentially lower number of unobservable, "hidden" variables, called factors. Observable variables are modeled as a linear combination of a small number orthogonal factors that are sources of common variability of the primary variables and a unique variance of each variable. Common factors may be interpreted as a source of a systematic risk and random component reflects the unsystematic (specific) risk. Factor analysis is often used as a data reduction method or a data classification method.

The first goal of the presented research is to identify common risk factors affecting CDS spreads of the countries surveyed, as well as factors specific to each country. Factor analysis as a method allowing a reduction in a large number of interrelated variables down to a few factors, without a significant loss of information contained therein seems to be a suitable for the purpose.

Each primary variable is presented as a linear combination of common and specific factors in the following way:

Dynamic Econometric Models 18 (2018) 99-114 


$$
\begin{aligned}
& Z_{t 1}=w_{11} F_{t 1}+w_{12} F_{t 2}+\cdots+w_{1 k} F_{t k}+V_{t 1} \\
& \cdots \\
& Z_{t i}=w_{i 1} F_{t 1}+w_{i 2} F_{t 2}+\cdots+w_{i k} F_{t k}+V_{t 1} \\
& \cdots \\
& Z_{t n}=w_{n 1} F_{t 1}+w_{n 2} F_{t 2}+\cdots+w_{n k} F_{t k}+V_{t n}
\end{aligned}
$$

where:

$Z_{t i}$ - standardized $i$-th variable at a moment $t, i=1,2, \ldots, n$,

$F_{t l}-l$-th common factor at a moment $t, l=1,2, \ldots, k$,

$w_{i l}$ - factor loading $l$-th common factor to $i$-th variable,

$V_{t i}$ - specific factor for the $i$-th variable at a moment $t$,

$n$ - number of primary variables,

$k$ - number of common factors.

Variance of the each variable is decomposed according to the following formula:

$$
\operatorname{var}\left(Z_{i}\right)=w_{i 1}^{2}+w_{i 2}^{2}+\cdots+w_{i k}^{2}+\psi_{i}^{2}=1,
$$

where $\psi_{i}^{2}$ - variance corresponding to specific factor.

Correlation between $p$-th and $q$-th variables can be obtained as follows:

$$
r_{p q}=\sum_{i=1}^{k} w_{p i} w_{q i}
$$

where $r_{p q}$ - correlation coefficient between $p$-th and $q$-th variable.

In matrix notation, a set of primary variables as present in the following way:

$$
\mathbf{Z}=\mathbf{F W}^{\mathbf{T}}+\mathbf{V},
$$

where:

$\mathbf{Z}$ - primary variables matrix $(\mathrm{t} \times n)$,

$\mathbf{F}$ - factor values matrix $(\mathrm{t} \times k)$,

$\mathbf{W}$ - factor loadings matrix $(\mathrm{n} \times k)$,

$\mathbf{V}$ - specific factors matrix $(\mathrm{t} \times n)$.

The decomposition of the covariance matrix of the primary variables is conducted as follows:

$$
\mathbf{R}=\mathbf{W W}^{\mathbf{T}}+\mathbf{\Psi},
$$

where:

$\mathbf{R}$ - variance-covariance matrix of a primary set of variables,

$\boldsymbol{\Psi}$ - covariance matrix for specific factors.

One of the ways to define the number of common factors is based on eigenvalues of variance-covariance matrix after factors extracted. In this study the minimum value of eigenvalues to be retained is 1 . 
After common factors are identified, factor loadings are calculated.

The next step is the decomposition of the CDS spread and measurement of the impact of the risk factors using the concept of factorization. The idea of factorization was introduced by Ho (1999), who used it for the decomposition of the total rate of return in the model CAPM for the bond market.

CDS spreads are presented according to the following formula:

$$
S_{t i}=w_{1 i} F_{t 1}+w_{2 i} F_{t 2}+\cdots+w_{k i} F_{t k}+V_{t i} \text { for } \mathrm{i}=1,2, \ldots, \mathrm{n}
$$

where:

$S_{t i}$ - CDS spread of a given country at a moment $t$,

$F_{t l}-l$-th common factor at a moment $t, l=1,2, \ldots, k$,

$V_{t i}$ - standardized specific factor at a moment $t$,

$n$ - number of primary variables,

$k$ - number of common factors.

All variables are standardized.

Proposed two-step methodology allows to measuring of the response of individual country to the change of common risk factors and obtaining a historical decomposition of CDS spreads.

\section{Characteristic of the Data}

Empirical analysis is performed for a set of 9 primary variables - these are CDS spreads for the following countries: Germany, France, Great Britain, Italy, Spain, Portugal, Czech Republic, Hungary and Poland for the period from 2008 to 2016 year. The data have daily frequency. The factor analysis as well the decomposition of the CDS spreads does not involve any macroeconomic data. The purpose is to identify factors ruling the evolution of spreads only based on the data concerning spreads.

Table 1 presents descriptive statistics of the data.

Table 1. Descriptive statistics of the data

\begin{tabular}{cccccc}
\hline Country & Mean & Median & Min & Max & Standard deviation \\
\hline DE & 24,88 & 20,94 & 6,64 & 92,50 & 16,67 \\
FR & 49,43 & 38,02 & 11,25 & 171,56 & 32,46 \\
GB & 48,48 & 42,82 & 11,66 & 165,00 & 27,70 \\
IT & 162,05 & 121,39 & 39,50 & 498,66 & 100,22 \\
ES & 154,34 & 113,97 & 37,00 & 492,07 & 100,51 \\
PT & 343,22 & 219,23 & 37,00 & 1521,50 & 315,49 \\
CZ & 80,22 & 69,24 & 33,00 & 350,00 & 46,87 \\
HU & 271,31 & 248,00 & 76,00 & 661,24 & 122,96 \\
PL & 119,31 & 92,78 & 43,50 & 421,00 & 66,50 \\
\hline
\end{tabular}

Note: DE - Germany, FR - France, GB - Great Britain, IT - Italy, ES - Spain, PT - Portugal, CZ - Czech Republic, HU - Hungary, PL - Poland. 
Table 2 reports correlation coefficients matrix.

Table 2. Correlation coefficients matrix

\begin{tabular}{cccccccccc}
\hline Country & DE & FR & GB & IT & ES & PT & CZ & HU & PL \\
\hline DE & 1,00 & 0,80 & 0,90 & 0,56 & 0,55 & 0,51 & 0,92 & 0,86 & 0,83 \\
FR & 0,80 & 1,00 & 0,55 & 0,86 & 0,85 & 0,85 & 0,69 & 0,57 & 0,81 \\
GB & 0,90 & 0,55 & 1,00 & 0,33 & 0,33 & 0,22 & 0,92 & 0,90 & 0,75 \\
IT & 0,56 & 0,86 & 0,33 & 1,00 & 0,93 & 0,87 & 0,51 & 0,41 & 0,76 \\
ES & 0,55 & 0,85 & 0,33 & 0,93 & 1,00 & 0,86 & 0,47 & 0,37 & 0,73 \\
PT & 0,51 & 0,85 & 0,22 & 0,87 & 0,86 & 1,00 & 0,42 & 0,27 & 0,63 \\
CZ & 0,92 & 0,69 & 0,92 & 0,51 & 0,47 & 0,42 & 1,00 & 0,96 & 0,87 \\
HU & 0,86 & 0,57 & 0,90 & 0,41 & 0,37 & 0,27 & 0,96 & 1,00 & 0,83 \\
PL & 0,83 & 0,81 & 0,75 & 0,76 & 0,73 & 0,63 & 0,87 & 0,83 & 1,00 \\
\hline
\end{tabular}

CDS spreads are highly correlated, thus factor analysis is suitable statistical procedure for this data set. It allows a reduction of the data dimension and identification the interrelationships among the primary variables and latent, common factors.

\section{Results}

At the first step of the study factor analysis revealed that two common factors have explained about $92 \%$ of the variation of the CDS spreads. These factors are unobservable, latent variables, but they may have some economic interpretation. Figure 1 presents common factors, labeled as F1 and F2.

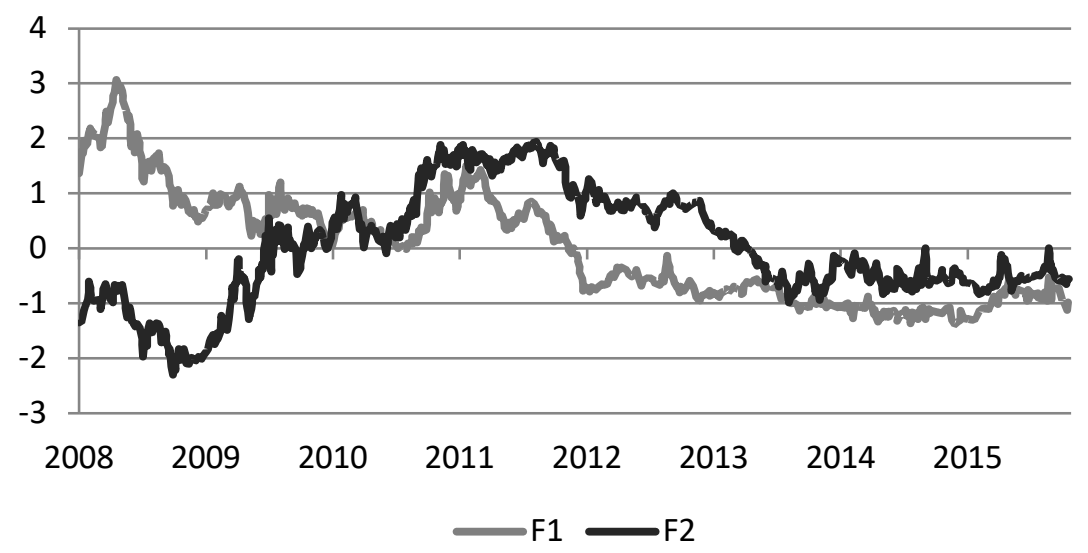

Figure 1. Common factors affecting CDS spreads

The first factor reached the maximum values at the turn of 2008-2009 years during the global financial crisis. Next, this factor increased in 2011. A hypothesis that this factor reflects a global risk will be investigated. 
Financial crisis from 2008 year influences the financial markets worldwide and contributed to the European sovereign-debt crisis in 2010 year. It can be expected that the first factor has influenced CDS spreads of all of the countries surveyed.

The second factor has different characteristics. It reached maximum values in 2011-2012 years when the Eurozone sovereign debt crisis exacerbated. This crisis has started in late 2009 and remained a critical factor at the sovereign credit market. Prior to the crisis the credit risk of Eurozone countries was considered to be very low; however, after the onset of the crisis, the credit risk has increased dramatically. It can be expected that second factor has influenced the countries with the biggest debt problems.

Next question is how these two common factors affect CDS spreads of the counties. Factor loadings obtained during the factor analysis show the influence of the factors on the CDS spreads. In order to obtain a clearer picture of these influences orthogonal varimax rotation was applied. Varimax rotation is orthogonal rotation that maximizes the sum of the variances of the squared loadings. It is achieved if any given variable has a high loading on a single factor but low loadings on the remaining factors. Factor loadings for each primary variable after varimax rotation are shown in Table 3.

Table 3. Rotated factor loadings, share of explained variation and unique variances

\begin{tabular}{cccc}
\hline \multirow{2}{*}{ Country } & \multicolumn{2}{c}{ Common factors } & \multirow{2}{*}{ Uniqueness } \\
\cline { 2 - 3 } & $\mathrm{F} 1$ & $\mathrm{~F} 2$ & 0,0816 \\
GB & $\mathbf{0 . 9 5 1 9}$ & 0.1111 & 0,0681 \\
CZ & $\mathbf{0 . 9 5 0 4}$ & 0.1691 & 0,0322 \\
PL & $\mathbf{0 . 9 3 6 1}$ & 0.3025 & 0,0852 \\
DE & $\mathbf{0 . 8 6 4 7}$ & 0.4088 & 0,1100 \\
HU & 0.7303 & 0.5972 & 0,0838 \\
FR & 0.4754 & $\mathbf{0 . 8 3 0 8}$ & 0,1036 \\
ES & 0.2220 & $\mathbf{0 . 9 2 0 4}$ & 0,0898 \\
IT & 0.2468 & $\mathbf{0 . 9 2 1 6}$ & 0,1329 \\
PT & 0.1367 & $\mathbf{0 . 9 2 1 1}$ & \\
Variation explained & 4.3214 & 3.8914 & 0,0874 \\
Share of variation & 0.4802 & 0.4324 &
\end{tabular}

Note: CZ - Czech Republic, PL - Poland, GB - Great Britain, DE - Germany, HU - Hungary, FR - France, ES - Spain, IT - Italy, PT - Portugal. Factor loadings higher than 0,8 is hig.

First common factor (F1) affects in the highest degree Great Britain, Czech Republic, Poland, and Germany. Second common factor (F2) affects mostly Portugal, Italy, and Spain. Hungary and France are under the influence of both common factors. Unique variance of the countries' CDS is between $3,22 \%$ (Poland) and 13,29\% (Portugal).

As CDS spreads of nine European countries evolved under the influence of two common factors, it is important to gave some economic explanation of 
these factors. Interpretation of the first common factor could be facilitated by comparing it to the Volatility Index (VIX), known as "fear index". The VIX Index is designed to produce a measure of constant, 30-day expected volatility of the U.S. stock market, derived from real-time, mid-quote prices of S\&P500 Index call and put options. On a global basis, it is one of the most recognized measures of volatility, widely reported by financial media and closely followed by a variety of market participants as a daily market indicator.

Figure 2 presents first common factor (F1) and volatility index. Correlation coefficient between two variables equals 0,75 .

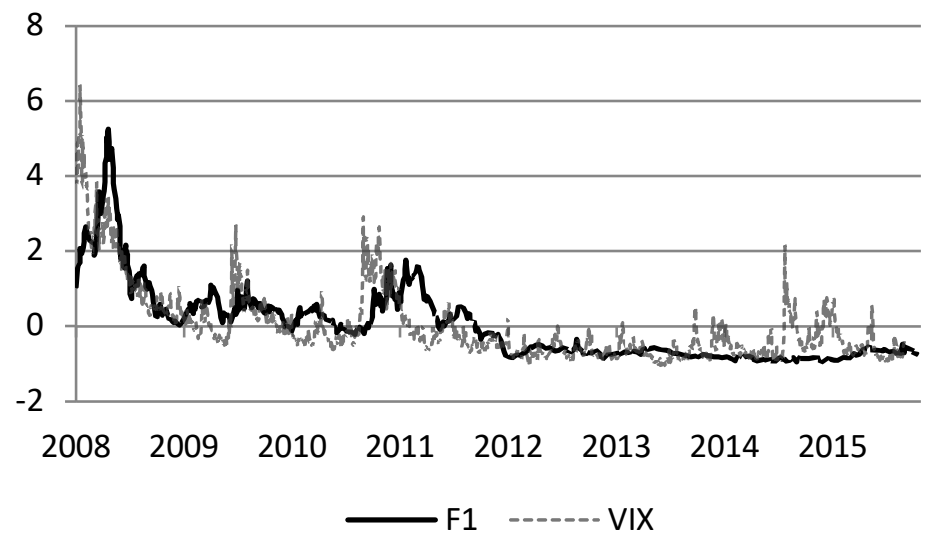

Figure 2. First common factor and index VIX

Second common factor affects at the largest extent countries with a highest indebtedness problems during the Eurozone debt crisis. Table 4 reports Government debt to GDP ratio for the surveyed countries. Countries are sorted in ascending order (in 2012 year).

Table 4. Government debt to GDP ratio (percentage)

\begin{tabular}{cccccccccc}
\hline Country & 2008 & 2009 & 2010 & 2011 & $\mathbf{2 0 1 2}$ & 2013 & 2014 & 2015 & 2016 \\
\hline CZ & 28,7 & 34,1 & 38,2 & 39,8 & $\mathbf{4 4 , 5}$ & 45 & 42,2 & 40 & 36,8 \\
PL & 46,3 & 49,4 & 53,1 & 54,1 & $\mathbf{5 3 , 7}$ & 55,7 & 50,3 & 51,1 & 54,2 \\
GB & 35,4 & 50,1 & 64,6 & 71,4 & $\mathbf{7 5 , 1}$ & 78,6 & 80,5 & 82,9 & 82,6 \\
HU & 71,6 & 77,8 & 80,5 & 80,7 & $\mathbf{7 8 , 2}$ & 76,6 & 76,6 & 77,7 & 76 \\
DE & 65,1 & 72,6 & 81 & 78,7 & $\mathbf{7 9 , 9}$ & 77,5 & 74,7 & 71 & 68,2 \\
ES & 39,5 & 52,8 & 61 & 69,5 & $\mathbf{8 5 , 7}$ & 95,5 & 100,4 & 99,4 & 99 \\
FR & 68 & 78,9 & 81,6 & 85,2 & $\mathbf{8 9 , 5}$ & 92,3 & 94,9 & 95,6 & 96,6 \\
IT & 102,4 & 112,5 & 115,4 & 116,5 & $\mathbf{1 2 3 , 3}$ & 129 & 131,8 & 131,5 & 132 \\
PT & 71,7 & 83,6 & 96,2 & 111,4 & $\mathbf{1 2 6 , 2}$ & 129 & 136 & 128,8 & 129,9 \\
\hline
\end{tabular}


Countries with the highest Government debt to GDP ratio after 2012 year are Portugal and Italy. Countries with the lowest ratio are Czech Republic and Poland.

In summary, based on the factor loadings and additional analysis, we can interpret two common factors as the global risk factor, and the Eurozone insolvency risk factor. These findings are in line with results presented by Ang and Longstaff (2013). They used the CDS for US Treasuries, US states, and major Eurozone countries. They found that the systemic risk component is related to global financial factors such as the VIX index. In the pricing model, they proposed the use of two types of credit events, systemic and sovereignspecific.

Presented in this paper results show that the source of volatility for CDS spreads shifted from the global risk factor in 2008 to the Eurozone insolvency risk factor in 2011.

The final step of presented research is a historical decomposition of CDS spreads, using the factorization framework. It allows to investigate which factor and to what extent affects the CDS spread of the given country. Consequently, it enables identification of investors' perception of the risk connected with investment in sovereign debt securities of this country. Historical decomposition is obtained using the equation (6), for $k=2$ common factors. Standardized CDS spread of each country is presented as a sum of three components, which indicate influence of two common factors and one specific to each country factor.

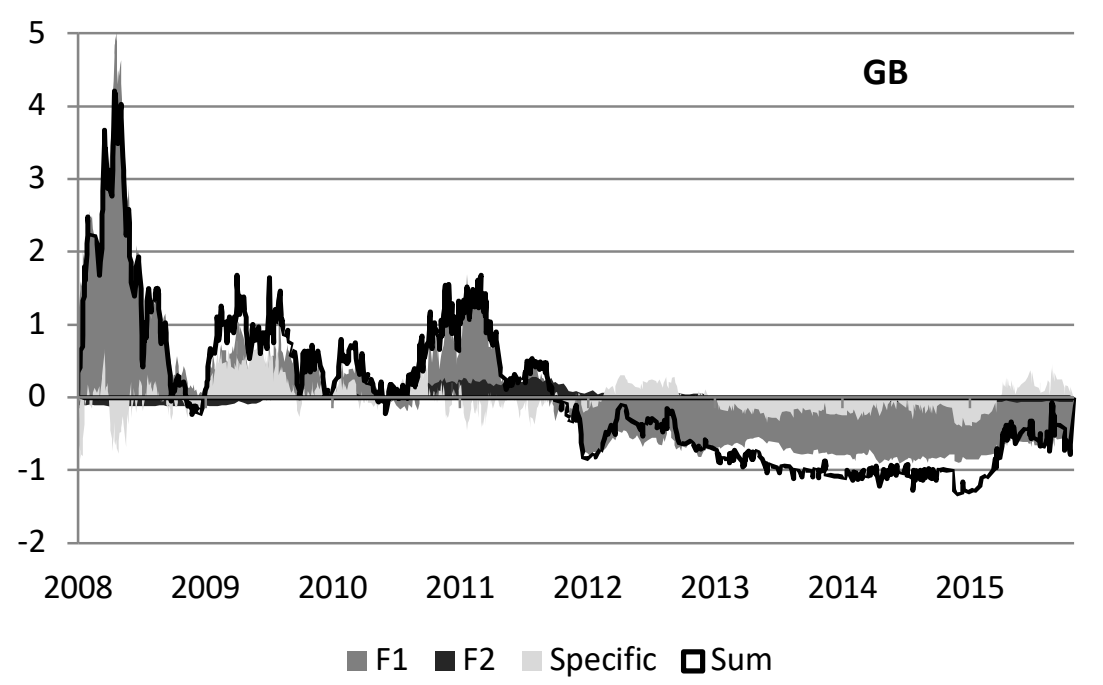

Figure 3. Decomposition of CDS spread of Great Britain 
Figures 3 to 6 show decomposition of CDS spreads for the first group of counties, correlated to the first common factor - Great Britain, Czech Republic, Poland and Germany.

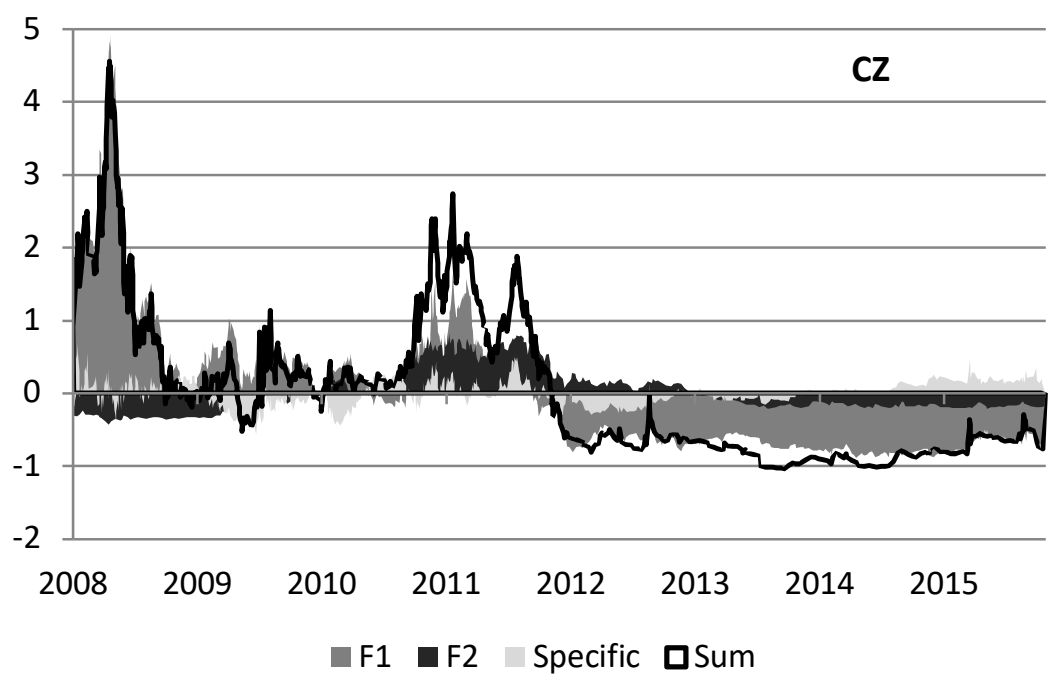

Figure 4. Decomposition of CDS spread of Czech Republic

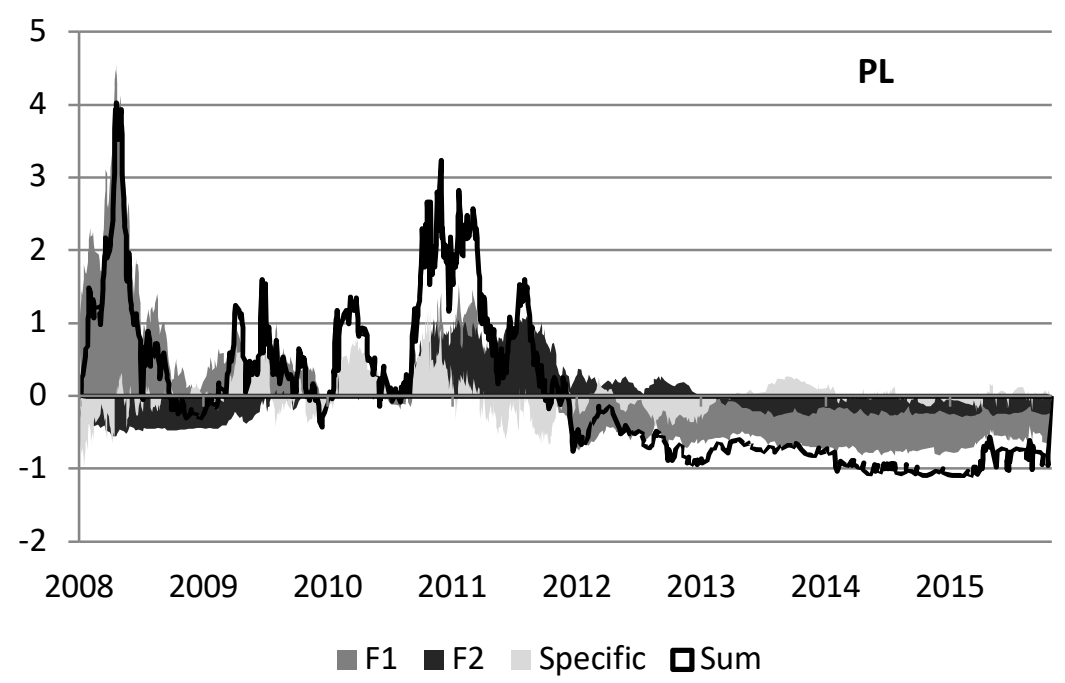

Figure 5. Decomposition of CDS spread of Poland 


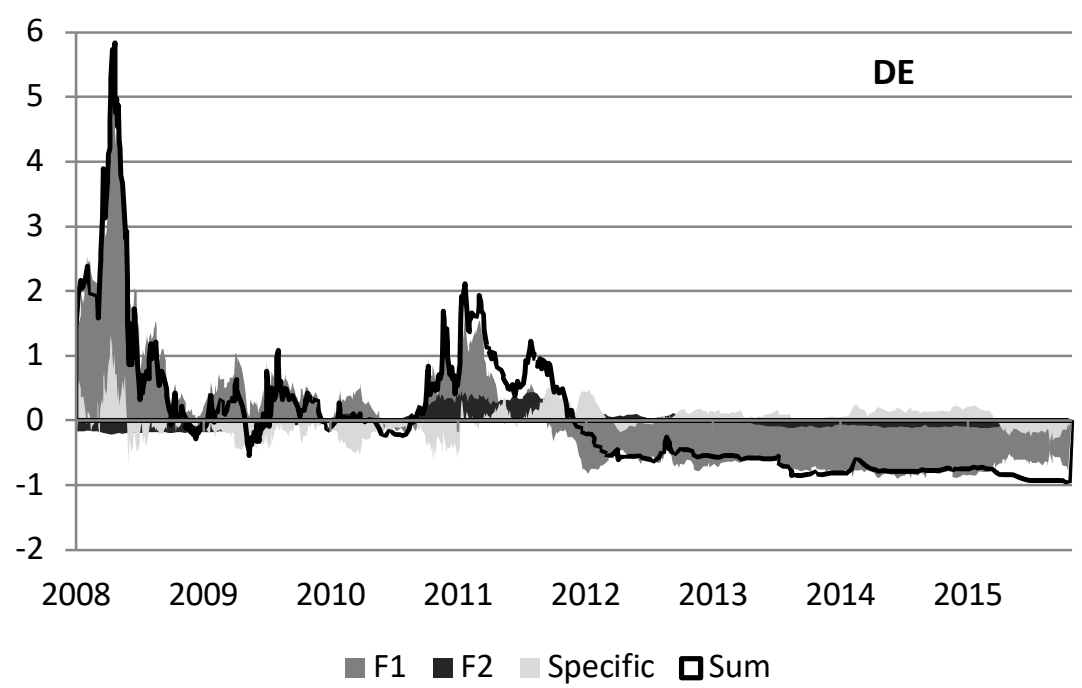

Figure 6. Decomposition of CDS spread of Germany

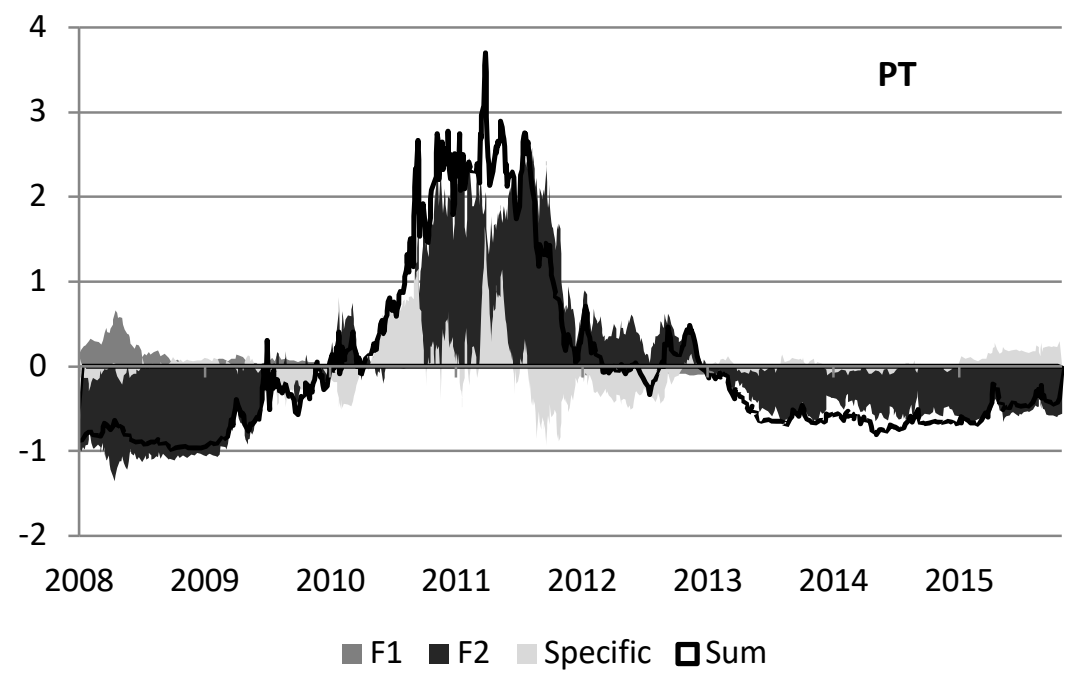

Figure 7. Decomposition of CDS spread of Portugal

Historical decomposition of CDS spreads of these countries revealed that CDS spread of these countries evolve mainly due to the influence of the first factor. The influence of the second factors is lower. But at the period of

Dynamic Econometric Models 18 (2018) 99-114 
insolvency crisis (2011 year) Poland and Czech republic are more influenced by the second factor than Great Briatan and Germany.

Figures 7, 8 and 9 present the decomposition of the CDS spread for the second group of countries, the most affected by the second common factorPortugal, Italy and Spain.

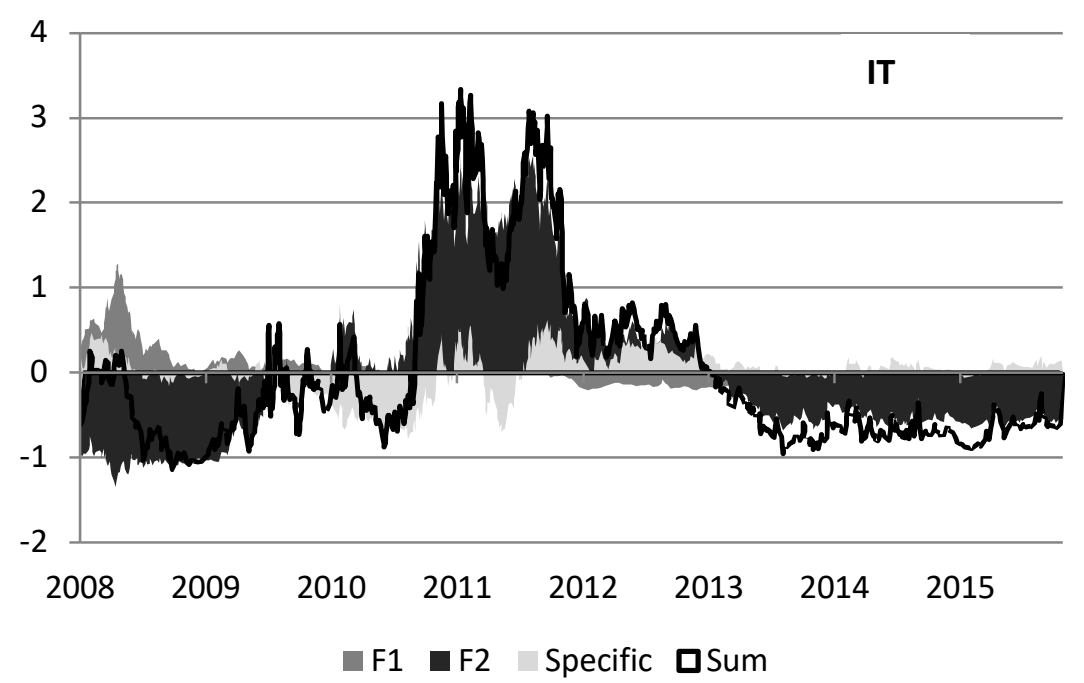

Figure 8. Decomposition of CDS spread of Italy

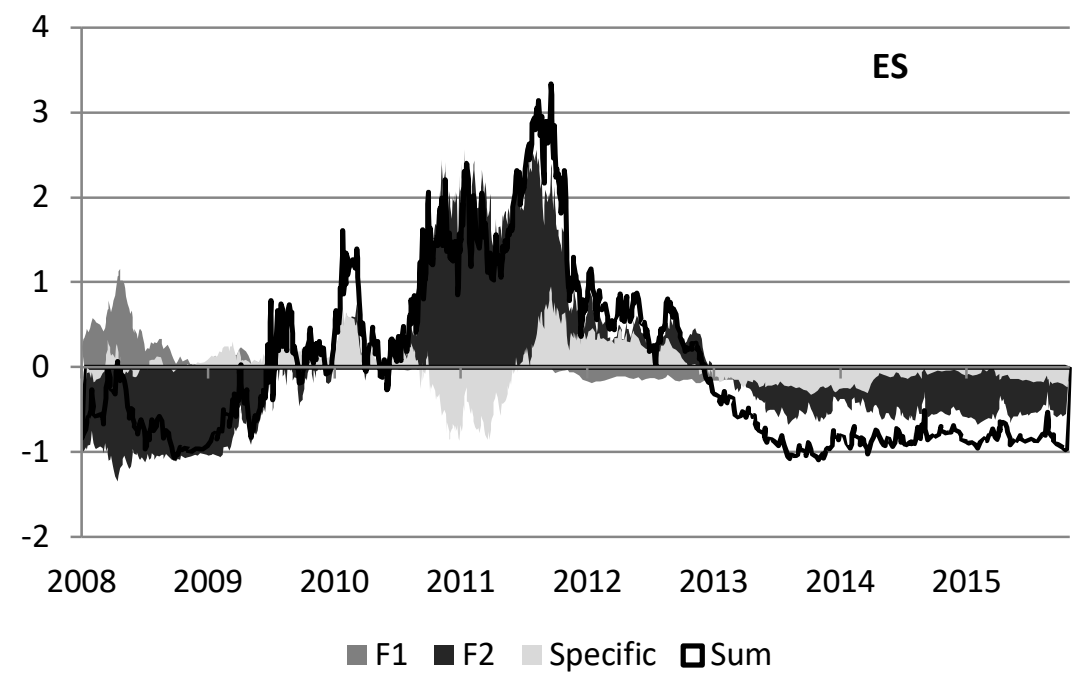

Figure 9. Decomposition of CDS spread of Spain 
The CDS spreads of these countries are influenced mainly by the second factor.

And last, France and Hungary - countries that are under the influence of both common factors. Figures 10 and 11 show the decomposition of CDS spread of these countries.

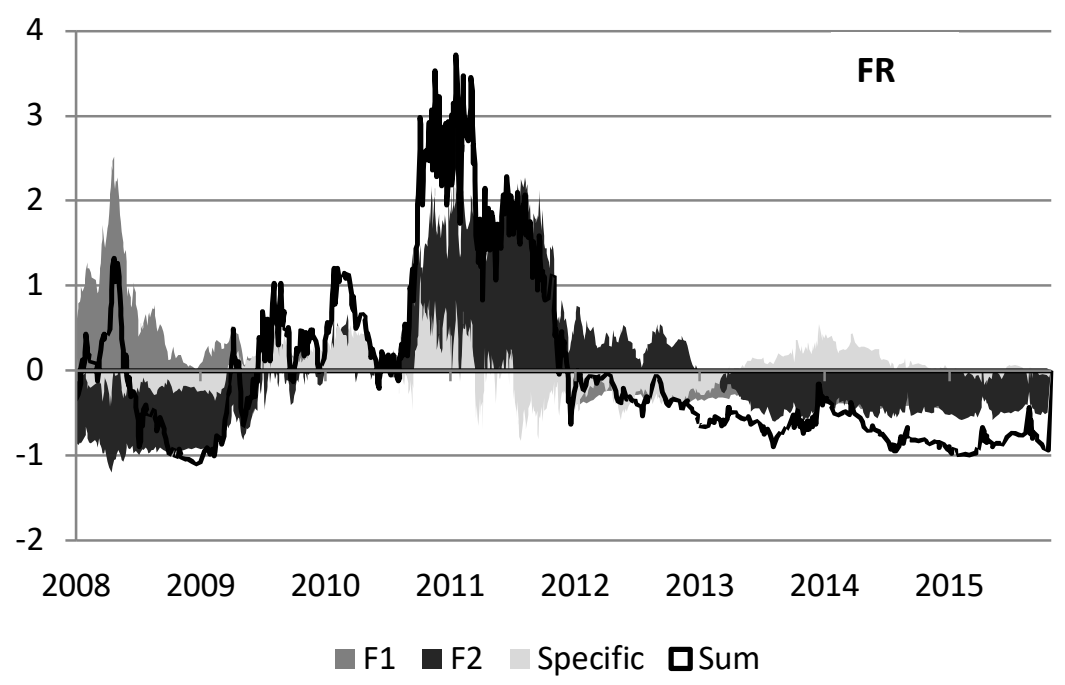

Figure 10. Decomposition of CDS spread of France

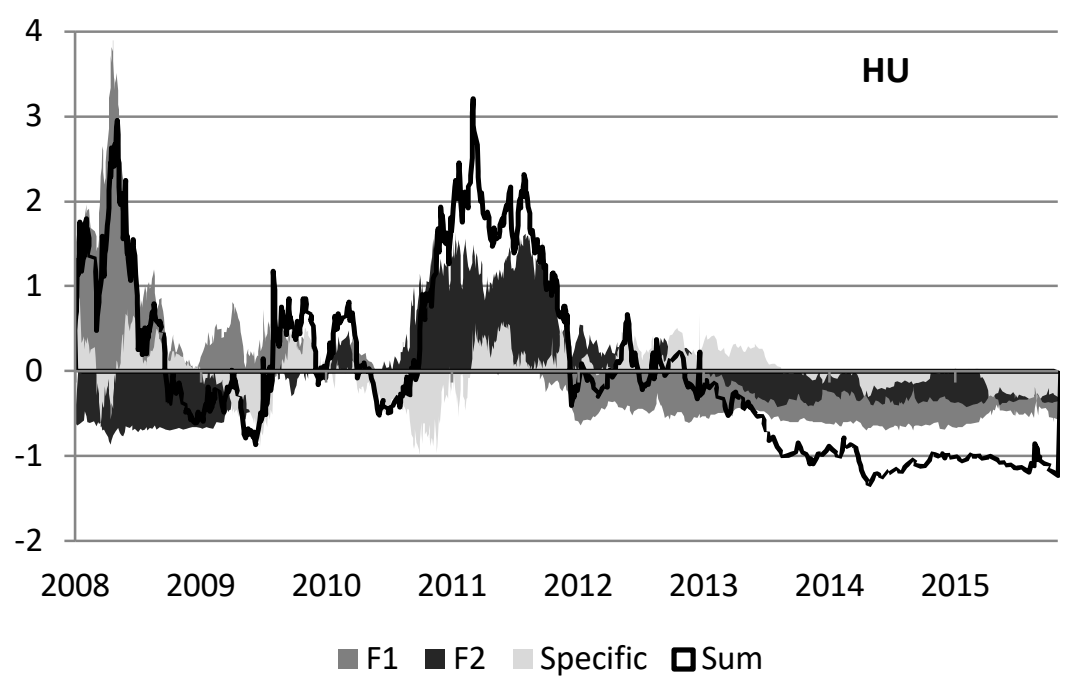

Figure 11. Decomposition of CDS spread of Hungary

Dynamic Econometric Models 18 (2018) 99-114 
Historical decomposition revealed the evidence that the sovereign CDS spreads are under combined influence of two common factors and one specific factor - time-varying and different for each country.

Summarising, first factor (F1) may be interpreted as a global risk factor, appearing during the crisis in 2008. It affected most of the countries, but in the larger extent influenced CDS spreads of Great Britain, Czech Republic, Poland and Germany. The second factor (F2) can be interpreted as an insolvency risk factor, it appeared in 2011-2012 years and influenced mainly the countries, which had debt problems - Portugal, Spain, Italy and to a lesser extent France and Hungary.

Comparative analysis shows that CDS spread of Poland's government debt reacts similarly to those of Czech Republic, Great Britain, and Germany. This leads to the conclusion that Poland treasury securities are considered by investors in a similar way as tree mentioned-above countries.

\section{Conclusions}

The presented analysis confirms that sovereign CDS spread is a measure of risk and it depends both on global risk factors (global financial market conditions, investor expectations etc.) as well as macroeconomic fundamentals (eg. level of indebtedness of the country). The factor analysis shows that two common factors explained about $92 \%$ of the variation of the CDS spreads of the surveyed countries. The results of decomposition of CDS spreads confirm that Great Britain, Poland, Czech Republic, and Germany are countries most influenced by the first common factor, interpreted as a global risk factor, appearing during the crisis in 2008. Portugal, Italy, and Spain are countries under the impact of the second common factor interpreted as an insolvency risk factor appearing in 2011-2012 years. France and Hungary are the countries influenced by both common factors.

\section{References}

Ang, A., Longstaff, F. A. (2013), Systemic Sovereign Credit Risk: Lessons from the U.S. and Europe, Journal of Monetary Economics, 60(5), 493-510, DOI: http://dx.doi.org/10.1016/j.jmoneco.2013.04.009.

Aizenman, J., Hutchison, M., Jinjarak, Y. (2013), What is the Risk of European Sovereign Debt Defaults? Fiscal Space, CDS Spreads and Market Pricing of Risk, Journal of International Money and Finance, 34, 37-59.

Arce, O., Mayordomo, S., Peña, J. (2013), Credit-Risk Valuation in the Sovereign CDS and bonds Markets: Evidence from the Euro Area Crisis, Journal of International Money and Finance, 35, 124-145.

Badaoui, S., Cathcart, L., El-Jahel, L. (2013), Do Sovereign Credit Default Swaps Represent a Clean Measure of Sovereign Default Risk? A Factor Model Approach, Journal of Banking and Finance, 37(7), 2392-2407. 
Bieńkowski, W., Gawrońska-Nowak, B., Grabowski, W. (2011) Podatność polskich rynków finansowych na niestabilności wewnętrzne i zewnętrzne, Materiały i Studia NBP. Zeszyt nr 258, NBP. (The Vulnerability of Polish Financial Markets to Internal and External Instabilities, Materials and Studies of the National Bank of Poland. No. 258, NBP.)

Büchel, K. (2013), Do Words Matter? The Impact of Communication on the PIIGS' CDS and Bond Yield Spreads during Europe's Sovereign Debt Crisis, European Journal of Political Economy, 32, 412-431, DOI: http://dx.doi.org/10.1016/j.ejpoleco.2013.08.004.

Coronado, M., Corzo, T., Lazcano, L. (2012), A Case for Europe: the Relationship between Sovereign CDS and Stock Indexes, Frontiers in Finance and Economics, 9(2), 32-63.

Coudert, V., Gex, M. (2013), The Interactions between the Credit Default Swap and the Bond Markets in Financial Turmoil, Review of International Economics, 21(3), 492-505.

Fabozzi, F. J., Giacometti, R., Tsuchida, N. (2016), Factor Decomposition of the Eurozone Sovereign CDS Spreads, Journal of International Money and Finance, Elsevier, 65(C), 1-23, DOI: http://dx.doi.org/10.1016/j.jimonfin.2016.03.003.

Ho, T. S. Y. (1990), Strategic Fixed Income Investment, Dow Jones-Irwing Homewood, Illinois

Kalbaska, A., Gątkowski, M. (2012), Eurozone Sovereign Contagion: Evidence from the CDS market (2005-2010), Journal of Economic Behavior and Organization, 83(3), 657-673.

Kliber, A. (2011), Sovereign CDS Instruments in Central Europe - Linkages and Interdependence, Dynamic Econometric Models, 11, 111-128.

Kliber, A. (2016), Impact of the Ban on Uncovered sCDS Trade on the Interdependencies Between the CDS Market and Other Sectors of Financial Markets. The Case of Safe and Developed versus Risky and Developing European Markets, Comparative Economic Research, 19(1), 77-99, DOI: http://dx.doi.org/10.1515/cer-2016-0005.

Komarek, L. Komarkova, Z., Lesanovska, J., (2013) Analysis of Sovereign Risk Market Indicators: The Case of the Czech Republic, Czech Journal of Economics and Finance, 63(1), 5-24.

Varga, L. (2008), The Information Content of Hungarian Sovereign CDS Spreads, MNB Occasional Papers, 78, 9-24.

\section{Dekompozycja spreadów kontraktów CDS na obligacje skarbowe przy zastosowaniu koncepcji faktoryzacji}

Z a r y s t r e ś c i. CDS (Credit Default Swap) na obligacje skarbowe to instrument pochodny, który stanowi ubezpieczenie spłaty długu rządowego i może być uważany za rynkowy wskaźnik ryzyka niewypłacalności danego kraju. Celem badania jest identyfikacja czynników wpływających na spready CDS wybranych krajów europejskich w okresie od 2008 do 2016 r. Na podstawie przeprowadzonej analizy czynnikowej stwierdzono, że istnieją dwa wspólne czynniki, które wyjaśniają około 92\% zmienności spreadów CDS. Następnie, dekompozycja spreadów CDS pokazuje wpływ tych czynników ryzyka na spready CDS badanych krajów.

S ł o w a k 1 u c z o w e: CDS spread; analiza czynnikowa; ryzyko globalne; ryzyko niewypłacalności. 